\title{
Antiquity
}

Vol. XXVII No. 108

DECEMBER I953

\section{Editorial Notes}

$\mathrm{T}$ THE year I953 has been, for us, a year of great achievements in mountaineering, aviation and sport, and our greatest man has been awarded the Nobel Prize for Literature. To these has now been added a comparable achievement in the world of pure scholarship-the decipherment by $\mathrm{Mr}$ Ventris of a hitherto unreadable script, called the Linear B script of Minoan Crete and the Mycenaean mainland. In their article on pages $233-7 \mathrm{Mr}$ Ventris and his collaborator, Mr Chadwick, give an account of their work, and those who want to know more about it can do so by reading their longer article in the current fournal of Hellenic Studies. They themselves emphasize the provisional nature of their solution, and no doubt it will be improved upon as time goes on ; we are quite sure that it is on thoroughly sound lines and its reception by qualified students has been very favourable. It is clear that the language of the script was an early form of Greek, which survived as the dialect of Arcadia. The clay tablets recording it were first found by Sir Arthur Evans at Cnossos in Crete. Just before the last war Professor Blegen found several hundred in the Palace of Nestor at Pylos on the tip of the Greek mainland, and recently a few have been found by Professor Wace at Mycenae; there are also a few graffiti from other mainland sites.

The Cretan tablets antedate the collapse of about I 400 B.C. when Cnossos was burnt and the political power of the Minoan dynasty ended. It now appears that the language of that dynasty was Greek ; in other words, that the Minos of tradition spoke Greek and his scribes wrote it. We still do not know when the Greek language was introduced into Crete; long before the fall another script, some of whose signs resemble Egyptian hieroglyphs, was in use, and it is presumed that the language was not Greek. The script read by Mr Ventris (Linear B) contains some of the signs used in the earlier Cretan hieroglyphic script, and a few more of the Linear A script that developed from the hieroglyphic. If Linear B was a modification of A there is a fair probability that Greek was introduced into Crete about $145^{\circ}$ B.C.

\section{(4)}

4

The historical background revealed by archaeology conforms well to that which we can dimly perceive behind the traditions. They speak of Minoan sea-power, of a great craftsman Daedalus who escaped from Minos and flew to Sicily, to the court of King Cocalus, whose Chief Engineer he became, and of an expedition organized by Minos to recapture him, but ending in disaster. Minos was treacherously killed by Cocalus and 


\section{ANTIQUITY}

buried in a tomb which Theron of Acragas (Agrigento) discovered early in the $5^{\text {th }}$ century B.c. This tomb was described by Diodorus Siculus, and it is clear that it closely resembled the famous Temple-tomb of Cnossos, dated about 1500 в.c. A 6th century inscription proves that the Daedalus-Cocalus tradition is ancient. No doubt it originated from the trading-stations in the west that were established by the Minoan dynasty before its fall.

On the Greek mainland powerful rivals of Minos were growing up, the chief of which was Mycenae, 'a citadel that commands a main artery of communications between the south-east and the north-west' (Childe, Dawn, p. 74). Though Mycenae was perhaps the most important, we must not overlook those others, possibly nearly or quite as important, whose extant archaeological remains are less evident ; there was a Mycenaean wall round the Acropolis of Athens whose ruler Theseus traditionally destroyed the Cretan Minotaur about the middle of the $\mathbf{1}^{\text {th }}$ century, and Daedalus was an Athenian. These mainland chiefs became wealthy in the usual feudal way, and imported or attracted craftsmen from Crete to make weapons and tools and to decorate their palaces. They traded with distant lands in Central Europe and the far west, and it may have been through their agency that the famous segmented faience beads, dated about 1400 B.C., reached Spain, France, England and Central Europe. It was certainly at this time that the axe cult, so much in evidence in Crete and Brittany, reached Stonehenge. We shall have more to say about this in our next number.

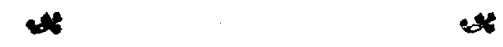

Having eliminated Minos the Achaeans of Mycenae took over his overseas trade and trading-stations and founded new ones. The evidence is archaeological; whereas the evidence for the earlier (Minoan) colonization of Sicily is mainly historical. But the archaeological types reveal so strong a Minoan influence that on those grounds 'Evans suspected a Cretan colonization of the island under a Minoan prince ' (Childe, Dawn, p. 232; quoting Evans, Palace of Minos $I, 3$ ). The earliest Aegean pottery found is certainly not Cretan and probably not of local manufacture ; examples from Sicily may perhaps be of Rhodian origin, though ' a mainland (Argolid) origin is not to be excluded. These vases belong as a whole to the I4th century; many of them are difficult to date, and some may perhaps be later' (T. J. Dunbabin: 'Minos and Daidalos in Sicily', Papers of the British School at Rome, vol.xvI, 1948, p.3). Metapontion on the Gulf of Taranto is traditionally said to have been founded by the companions of Nestor of Pylos, and the wanderings of Odysseus 'may reflect Minoan voyages in the Western Mediterranean' (Dunbabin, loc. cit., p. 13). Eastwards the Mycenaeans must have come into contact with the Hittites; we surely need not hesitate to equate the Ahhiyawa of the Hittite inscriptions with the Achaeans (=Mycenaeans ?), and the occurrence of the word Akawija on a Cretan tablet supports the identification, as Mr Ventris has already pointed out. The king of the Ahhiyawa was sufficiently important in the 13 th century to be mentioned with the kings of Egypt, Babylon and Assyria, as one of the great powers of the times (O. R. Gurney, in The Hittites, Penguin, p. 50). There was a Mycenaean settlement at Enkomi near Famagusta in Cyprus, and a palace was built there about $135^{\circ}$ B.c. (see also pp. 233-7 below). There were Mycenaean trading-stations on the Syrian coast, and others will probably be found on the southern shores of Anatolia, especially of the Gulf of Adalia, when that region is explored by field-archaeologists. 


\section{EDITORIAL NOTES}

The eastward expansion was probably made possible by the destruction of Cretan sea-power. Later, about I200 B.c. came the great sea-raids on Egypt, and last of all the Trojan War. Troy barred the way to the Black Sea round whose shores was so much raw material. The Argonauts slipped through on what may have been a preliminary, but very profitable, reconnaissance. Heracles had an encounter with Priam's father Laomedon, and the walls of Apollo which he attacked may have been identified by Greek folk-tradition with those of the Sixth City, fully described in Prof. Blegen's last volume (Troy III, Princeton Univ.). The Achaeans under Agamemnon decided to remove the obstacle once and for all, thinking no doubt that they were the first to whom such an idea had occurred. The traditional date of the Trojan War is II94-84 B.c. and it has stood up to the test of modern discoveries very well. It would, however, be premature to express any but a guarded opinion until Blegen's fourth and last volume appears, dealing with the Homeric cities.

\section{*}

Some elements of the Linear B script were incorporated in the script of Cyprus. The longest text in Cypro-Minoan is the one published for the first time in the present number of ANTIQUITY (pp. 233-7), found by Mr Dikaios in the Mycenaean city of Enkomi. The script cannot yet be read, nor is it known in what language it is written; a prime condition of deciphering it is the discovery of a large number of tablets, so that experiments and comparisons may become possible. There would seem to be a fairly good chance of this happening, and one would like to congratulate the discoverers of this highly important object, and to wish them the luck of finding more.

\section{$*$}

In his note $\mathrm{Mr}$ Dikaios refers to the discovery nearby in 1948 of a ' remarkable bronze statue of a male god wearing a headdress adorned with bull's horns'. In his Archaeology of Crete (1939, p. 231) Pendlebury says of the ruler of Cnossos: 'Dare we believe that he wore the masque of a bull ?' In other words, that Minos was himself the Minotaur-the priest-king slain by Theseus. The discovery of just such a representation as Pendlebury imagined on a Mycenaean site of the right date is an answer to Pendlebury's daring question, even though it comes not from Crete but from Cyprus.

\section{$*$}

In conclusion one may attempt to assess the present position and future prospects. There exist many hundreds of Linear B tablets, consisting mostly of inventories and with little consecutive text; and there is one tablet in a kindred but unreadable script that may be a poem; we can read the one and not the other. In spite of all the excavation that has been done in Crete and Greece nothing comparable to the Hittite and other archives has been found; but in Crete the Phaistos disc, in Linear A, seems to have refrains and therefore to be metrical or poetical. It is dated about I600 B.C., and an Anatolian connection has been suggested. Valuable though even such inventories are, archives with consecutive texts would be much more so. For the immediate future we want more of the Cypro-Minoan script, so as to be able to try and decipher it. For the rest, a field survey of the Anatolian coastal sites to the north might be made, in the hope of finding Mycenaean potsherds and thus pointing the way to the future excavation. 